\title{
Ecology and Management of Kermes Oak (Quercus cocci- fera L.) Shrublands in Greece: A Review
}

\author{
CONSTANTINOS N. TSIOUVARAS
}

\begin{abstract}
Kermes oak (Quercus coccifera L.) shrublands occupy more than 0.4 million ha in Greece and are the typical browse rangelands for 4.5 million goats. Five "range types" of kermes oak were identified based on morphological differences. Clipping of kermes oak improves growth rate of twig length, increases the production of new twigs, and alters the nutritive value of browse. Kermes oak can withstand very heavy (100\%) clipping of twigs for 2 consecutive years, yielding the highest growth rate and twig number. Browse production varies among different forms of kermes oak shrublands. The low form (0.5- $0.8 \mathrm{~m}$ height) yielded the highest production $(3,467 \mathrm{~kg} \cdot \mathrm{ha}-1)$. Goat liveweight gain of tall form ( $2 \mathrm{~m}$ height) of kermes oak shrubland was $25 \mathrm{~kg} \cdot \mathrm{ha}^{-1}$ • $\mathrm{yr}^{-1}$; improved shrublands, by topping, produced double liveweight gain when their form was altered. Liveweight gain was almost quadrupled when kermes oak shrublands were converted to grasslands.
\end{abstract}

Key Words: kermes onk, Quercus coccifera, Mediterranean shrublands, maquis, garrigue, shrubland management

The extensive shrublands of sclerophyllous evergreen shrubs and small trees around the Mediterranean basin are known as garrigue or maquis. This type of shrubby vegetation has characteristics similar to chaparral vegetation of the Western U.S.A. Kermes oak (Quercus coccifera L.) ${ }^{1}$ is the dominant species of Mediterranean shrublands. It can grow in a range of soil types, from mesic acidic to xeric calcareous soils (Moulopoulos 1965). According to Le Houerou (1974), typical areas where kermes oak shrublands grow are characterized by limestone soils and semidry to humid Mediterranean climate, with annual rainfall from $\mathbf{4 0 0}$ to $1,200 \mathrm{~mm}$, with warm to cool winters.

Kermes oak shrublands cover an area of more than 2 million ha throughout the Mediterranean countries (Le Houerou 1974) and are mainly used for browsing by livestock (Le Houerou 1972). They cover more than 0.4 million ha in Greece (Liacos et al. 1980) and are the typical browse rangelands for 4.5 million goats (Pittas 1980). Kermes oak extends from Eumediterranean zone (Quercetalia ilicis) to Submediterranean (Quercetalia pubescentis) (following the Braun-Blanquet classification), forming pure stands or mixed with other species such as Quercus ilex L., Arbutus spp. in the former, and Carpinus orientalis Miller and Quercus pubescens Willd. in the latter. It grows at heights up to $1,200 \mathrm{~m}$ in South Greece and the islands, and $700 \mathrm{~m}$ (on south facing slopes) in North Greece (Dafis 1973, Mavrommatis 1980). A large part of kermes oak shrublands represent a degraded stage of former high forests of warm-region pines and oaks (Moulopoulos 1965, Dafis 1973).

Besides the ecological, watershed, and recreational importance of kermes oak shrublands, they are also of considerable economic importance for Greece, supporting livestock by providing nutritious food during critical periods, such as summer, when grasses and forbs are dry, and winter, when snow covers the mountain rangelands. For these reasons, the Department of Range and Wildlife Science at the University of Thessaloniki and the Forest Research Institute of Thessaloniki have studied growth characteristics and nutritive value of kermes oak as well as the productivity, improvements, and management of kermes oak

\footnotetext{
Author is senior lecturer, Dept. of Range and Wildlife Science (236) School of Forestry and Natural Environment, Aristotelio University of Thessaloniki, Greece. Manuscript accepted 29 June 1987 .
}

IPlant names and authorities according to "Flora Europaea" (Tutin et al. 1964-1980) brushlands since 1955. The purpose of this paper is to summarize the results of these projects, and to make management suggestions.

\section{Study Area}

Most of the research projects were carried out at Chrysopigi, near the town of Serres, in Macedonia, Greece $\left(41^{\circ} 15\right.$ North latitude and $23^{\circ} 2758$ East longitude), in an area at a height of 650 $\mathrm{m}$, with $650 \mathrm{~mm}$ annual rainfall and $13^{\circ} \mathrm{C}$ mean annual temperature. The climate of the area is characterized as subhumid with cold winters (Emberger 1942). The soils are derived from conglomerates (sea deposit) of the tertiary period and are of medium depth, slightly acid, and sandy silt loam in texture. Kermes oak grows in almost pure $(90 \%)$ stands.

\section{Growth Characteristics}

Kermes oak can grow into a small tree, but it is usually found as a shrub with a height of less than $2 \mathrm{~m}$, due to centuries of use by man (cutting, fires, overgrazing) (Moulopoulos 1965, Dafis 1973). Under these conditions, it creates a multi-branched and multistemmed crown with evergreen, hard, oval-shaped, and spiny leaves. It also develops a deep root system and sprouts vigorously from the stump and from the roots (Papanastasis and Liacos 1980).

Kermes oak shows subspecific variation which permits at least 5 different morphological types to be distinguished (Liacos and Moulopoulos 1967). Based on the morphological variations of dominant shrubs, a "key" was developed, for the identification of the 5 "range types" of kermes oak (Liacos and Moulopoulos 1967). These types may grow on the same or different sites.

At Chrysopigi, kermes oak starts new growth (bud elongation) in the first half of April and the young twigs appear at the end of April or early May (Tsiouvaras 1984). The growth pattern of kermes oak appears to be affected by grazing. Tsiouvaras et al. (1986) found that clipping $20 \%, 40 \%, 60 \%, 80 \%$, and $100 \%$ of the current twig growth (expressed in length), repeated every 15 days, from early May through late September, stimulated growth during the summer and gave significantly higher growth rates (Table 1). The control, after approximately $\mathbf{4 0}$ days of spring growth, stopped growing in early June and remained dormant until late summer. A second growth of the control plants appeared in late August, from buds that formed during the same growing season. This is similarly reported for oak species by Kramer and Kozlowski (1960).

Kermes oak, alone or mixed with other evergreen shrubs, forms the understory of warm region pine forests (Pinus halepensis Miller and $P$. brutia Ten.) in Greece. The growth characteristics of kermes oak growing in forest understory appears to be different from those of kermes oak growing in full sunlight. Koukoura (1984) reported that annual twig growth and leaf area ratio were higher for shrubs growing as pine forest understory than in full sunlight $\left(4.6 \mathrm{~cm}\right.$ and $3.1 \mathrm{~cm}, 0.35$ and $0.19 \mathrm{dm}^{2} \bullet \mathrm{g}^{-1}$ respectively). The leaves of individuals growing in full sun have a thicker epidermis and mesophyll and a higher average weight than those growing in the understory $(0.030 \mathrm{~g}$ and $0.024 \mathrm{~g}$ respectively) (Koukoura 1984); this can be considered a morphological adaptation of kermes oak to the intense sunlight of the areas where it grows. 


\section{Browse and Biomass Production and Utilization}

The browse production of kermes oak varies among the 5 range types identified by Liacos and Moulopoulos (1967). The browse production of a dense and $2 \mathrm{~m}$ tall kermes oak brushland ranged from $742 \mathrm{~kg} \bullet \mathrm{ha}^{-1}$ (dry matter) in the most productive type to 378 $\mathrm{kg} \bullet \mathrm{ha}^{-1}$ in the least productive. The browse production in a kermes oak garrigue in southern France, with structure similar to the Greek one, averaged a total of about $1,000 \mathrm{~kg}$ of dry matter per ha (Long et al. 1967). The higher production is most likely a result of the wetter climate of the French study site $(800-1,000 \mathrm{~mm}$ annual rainfall) as compared to the Greek study site $(630 \mathrm{~mm}$ annual rainfall).

Much greater browse production was measured in a kermes oak shrubland developed from sprouts $(0.5 \mathrm{~m}$ in height) after tall shrubs ( $2 \mathrm{~m}$ in height) were cut at ground level during the summer of 1974. Goats grazed on the sprouts from October of 1974 through December of 1977. The dry matter browse production was measured in 1981 and 1982 and averaged $3,497 \mathrm{~kg}^{\circ} \mathrm{ha}^{-1} \bullet \mathrm{yr}^{-1}$ (Tsiouvaras 1984).

Besides the high browse production, kermes oak shrublands also support high above-ground biomass. Three years after a wildfire in an area of northern Greece with a semiarid climate, the biomass production of evergreen shrublands, of which kermes oak was the main component, increased linearly and augmented by about 2,000 $\mathrm{kg} \bullet \mathrm{ha}^{-1}$ from 1 year to the next (Papanastasis 1978). In a kermes oak shrubland in southern France, the above-ground biomass up to $30 \mathrm{~cm}$ was found to be 46 tons of dry matter per ha (Long et al. 1978), while Trabaud (1977) maintains that a kermes oak garrigue reestablishes its prefire state in about 5 years following a fire. These data indicate the high productive potential of these shrublands.

In order to find easier and less time-consuming methods to determine the browse production and utilization of kermes oak, Tsiouvaras (1978) studied the relationships of some important growth parameters (twig weight, diameter, and length) and developed linear and parabolic regression equations, as follows:

1) Twig weight (w) in relation to diameter (d) at $2 \mathrm{~mm}$ above the twig base: $w=-0.1624+2.1418 \mathrm{~d}$, with $r^{2}=0.939, \mathrm{n}=255, s_{\mathrm{w} . \mathrm{d}}=0.031$, and $s_{w}=0.0079$

2) Twig length (l) in relation to diameter (d): $1=1.6358+53.36 \mathrm{~d}-96.833 \mathrm{~d}^{2}$, with $r^{2}=0.590, \mathrm{n}=257, \mathrm{~s}_{1 . \mathrm{d}}=0.498$, and $s_{1}=0.0483$

3) Twig weight (w) in relation to length (l): $\mathrm{w}=0.07443+0.04615 \mathrm{l}$, with $r^{2}=0.919, \mathrm{n}=258, \mathrm{~s}_{\mathrm{w} .1}=0.037$, and $\mathrm{s}_{\mathrm{w}}=$ 0.0080 , where $n=$ sample size, $s_{w}=$ standard deviation and $s_{w .1}=$ standard error of estimate.

Weight is expressed in grams, while diameter and length are in centimeters. All coefficients of correlation were statistically significant at the probability level of 0.05 . By using these equations, the original (before grazing) weight or length of a twig can be estimated by measuring the diameter at $2 \mathrm{~mm}$ above the base (first 2 equations). Then, by measuring the weight or length of the remaining part (after grazing) of the twig, the percentage use in weight or in length can be estimated. The twig weight (browse production) can also be estimated by measuring its length (third equation), a much easier procedure than measuring its weight. Furthermore, the browse production of a given area can be calculated by estimating the mean twig weight using the mean twig length ( $n=258$ ), and multiplying this weight by the total twig number for the given area (obtained after sampling).

Kermes oak has survived fire and grazing through the centuries, due to its strong resprouting ability. Tsiouvaras (1984) found that kermes oak sustained $100 \%$ clipping of current twig growth, every 15 days for 2 consecutive years, giving, on average, significantly higher growth rates and higher numbers of new twigs, as compared to other clipping intensities and the control (Table 1). Shrubs treated with $80 \%$ clipping, also maintained high vigor at the end of the 2-year period. This indicates the high degree of utilization that kermes oak can sustain for a period of at least 2 years.
Table 1. Average (2 years) of twig number (twig $\cdot$ year $^{-1}$ ) and twig growth rate $\left(\mathrm{cm} \bullet\right.$ day $\left.^{-1}\right)$ of kermes oak subjected to various clipping intensities (After Tsiouvaras 1984 and Tsiouvaras et al. 1986).

\begin{tabular}{lccccccc}
\hline & \multicolumn{5}{c}{ Percentage of current growth clipped } \\
\cline { 2 - 7 } & $\begin{array}{l}\text { Control } \\
(0 \%)\end{array}$ & $20 \%$ & $40 \%$ & $60 \%$ & $80 \%$ & $100 \%$ \\
\hline Total annual & & & & & & & \\
Twig number & $1459 \mathrm{e}^{1}$ & $1966 \mathrm{~d}$ & $2319 \mathrm{c}$ & $2687 \mathrm{~b}$ & $2726 \mathrm{~b}$ & $3206 \mathrm{a}$ \\
twig growth rate & $31.3 \mathrm{c}$ & $31.5 \mathrm{c}$ & $40.0 \mathrm{~b}$ & $42.6 \mathrm{~b}$ & $39.8 \mathrm{~b}$ & $56.9 \mathrm{a}$ \\
\hline $\begin{array}{l}\text { TMeans in the same row sharing the same letter are not significantly different at the } \\
0.05 \text { level }\end{array}$
\end{tabular}
0.05 level.

Liacos and Moulopoulos (1967) found that goat preference varied among the 5 kermes oak range types. This was due to the different nutrient content and palatability of the 5 types. Regardless of type, kermes oak was browsed less when mixed with other more palatable browse species. The results of a 3-year grazing trial showed that 6 to 12-month-old goats utilized kermes oak up to 70\%, while for Quercus pubescens Will., Fraxinus ornus L. and Carpinus orientalis Miller sprouts, utilization was $95 \%$; but kermes oak was preferred by goats to Cistus incanus L. (30\% utilization) (Liacos et al. 1980).

\section{Nutritive Value}

The 5 range types of kermes oak have a varying nutrient content throughout the year (Liacos and Moulopoulos 1967). The crude protein content ranges between 13\% in May and 6.3\% in December in the most productive type, while it ranges between $11.5 \%$ and $6 \%$ in the less productive type. The most productive type had a lower crude fiber content ( $18 \%$ in May and $24 \%$ in December) than the less productive type ( $20 \%$ and $28.8 \%$, respectively).

In an experiment with goats fed in metabolism cages, the nutritive value of kermes oak at 4 discrete phenological stages was determined (Nastis 1982). Methods used were Kjeldahl analysis (AOAC 1975) for nitrogen determination, the two-stage digestion technique (Tilley and Terry 1963) for the in vitro dry matter digestibility, Van Soest (1967) for cell contents, Van Soest (1963) for lignin, and Street et al. (1964) for urine energy content determinations. Shrub foliage was harvested daily and offered fresh to goats for 10 days during the spring (rapid growth), summer (stem hardening), early fall (secondary growth), and winter (dormancy). The year-round nutrient content of feed was almost constant (Table 2) despite the variation by season in browse foliage availa-

Table 2. Nutritive value of kermes oak browse consumed by goats, and 2 supplements, in comparison to alfalfa forage (After Nastis 1982).

\begin{tabular}{lcccc}
\hline & & \multicolumn{3}{c}{ Acid } \\
& $\begin{array}{c}\text { Crude } \\
\text { Protein } \\
\text { Feed }\end{array}$ & $\begin{array}{c}\text { Cell } \\
\text { Contents } \\
\%\end{array}$ & $\begin{array}{c}\text { detergent } \\
\text { Fiber }\end{array}$ & $\begin{array}{c}\text { Lignin } \\
\%\end{array}$ \\
\hline Spring browse & 7.8 & 50 & 38 & 13.8 \\
Summer browse & 6.5 & 45 & 37 & 15.1 \\
Fall browse & 7.2 & 48 & 37 & 16.1 \\
Winter browse & 7.1 & 48 & 37 & 16.2 \\
Sugar beet pulp & 9.1 & 51 & 27 & 3.4 \\
Soybean meal & 44.6 & 69 & 10 & 0.7 \\
Alfalfa & 16.9 & 57 & 31 & 10.6 \\
\hline
\end{tabular}

ble. This was probably a result of the selective browsing by the goats. After stem elongation had ceased (late summer), the apparent digestibility was drastically reduced together with the digestibility of crude protein and total energy (Table 3). Therefore, digested crude protein and digested energy of kermes oak browse were inadequate for the maintenance demands of goats in all 
Table 3. Apparent dry matter (DM), crude protein (CP), and total energy (E) digestibility by goats of oak browse with or without a supplement, in comparison to an alfalfa forage (After Nastis 1982).

\begin{tabular}{lccc}
\hline \hline Feed & $\begin{array}{c}\text { DM } \\
\text { digest. }\end{array}$ & $\begin{array}{c}\mathrm{CP} \\
\text { digest. }\end{array}$ & $\begin{array}{c}\mathrm{E} \\
\text { digest. }\end{array}$ \\
\hline Spring browse & $70^{1} \mathrm{a}$ & $66 \mathrm{a}$ & $70 \mathrm{~b}$ \\
Summer browse & $53 \mathrm{~b}$ & $42 \mathrm{ab}$ & $49 \mathrm{c}$ \\
Fall browse & $55 \mathrm{~b}$ & $46 \mathrm{ab}$ & $54 \mathrm{c}$ \\
Winter browse & $56 \mathrm{~b}$ & $44 \mathrm{ab}$ & $53 \mathrm{c}$ \\
W.f. ${ }^{2}+$ sugar beet pulp & $54 \mathrm{~b}$ & $25 \mathrm{~b}$ & $51 \mathrm{c}$ \\
W.f. + soybean meal & $55 \mathrm{~b}$ & $60 \mathrm{ab}$ & $51 \mathrm{c}$ \\
Alfalfa & $79 \mathrm{a}$ & $77 \mathrm{a}$ & $80 \mathrm{a}$ \\
\hline
\end{tabular}

'Means in the same column sharing the same superscript are not significantly different at the 0.05 level.

2W.f. = winter foliage

seasons but spring. Furthermore, nutrients from spring foliage were insufficient for lactation. Goats gained weight when consuming alfalfa, foliage from spring collection, or when their diet was supplemented. They lost weight when they consumed only browse collected during the summer, fall, and winter.

Grazing seems to alter the nutritive value of kermes oak browse by stimulating the plant to regrow and thus offer more nutritious forage to grazing animals. Tsiouvaras (1984) estimated crude protein, cell contents, and dry matter digestibility of browse from kermes oak plants subjected to various clipping intensities and from a control. Methods used were Kjeldahl analysis (AOAC 1975) for nitrogen determination, Van Soest (1967) for cell contents, and two-stage digestion technique (Tilley and Terry 1963) for the in vitro dry matter digestibility determinations. The results indicated significant differences, in all of the constituents, between the control and the clipping intensities. Significant differences also existed among the clipping intensities (Table 4) but only with regards to dry matter digestibility and cell contents. These seemed to be related to changes in cell structure as the twig elongates from the apical bud to twig base (Short et al. 1972, Fahn 1974). As the clipping intensity increased, the sample of browse consisted of longer twig pieces, containing more lignified cells.

A very interesting point is the rate of change in crude protein from early spring to early fall, in all clipping intensities and the control (Table 5). The values of digestible protein for maintenance, gestation and lactation (Cook 1972, Le Houerou 1980) can be converted into crude protein using the equation $y=1.1 x-4.6$, with $r^{2}=0.960, \mathrm{n}=28$, and $\mathrm{s}_{\mathrm{y} . \mathrm{x}}=1.5$, where $\mathrm{y}=$ digestible protein, $\mathrm{x}=$ crude protein, $n=$ sample size and $s_{y . x}=$ standard error of estimate, established by Nastis (1982) for kermes oak growing in the same area and grazed by goats. When the values of crude protein given by the equation are compared to those from the clipping intensities and the control, one can conclude that browsing at any intensity offers new and more nutritious forage to grazing goats, with sufficient protein content, even for lactation, from spring (rapid growth) through to early fall (secondary growth). Forage of ungrazed shrubs does the same in early spring only, as Nastis (1982) also reports.
Table 4. Crude protein (CP), in vitro dry matter dizestibility (IVDMD), and cell contents $(\mathrm{CC})$ of kermes oak browse under various clipping intensities (After Tsiouvaras 1984).

\begin{tabular}{|c|c|c|c|c|c|c|}
\hline \multirow[b]{2}{*}{ Control } & \multicolumn{6}{|c|}{ Percentage of current growth clipped } \\
\hline & $0 \%$ & $20 \%$ & $40 \%$ & $60 \%$ & $80 \%$ & $100 \%$ \\
\hline$\overline{\mathrm{CP}}$ & $9.3^{1} \mathrm{~b}$ & $11.8 \mathrm{a}$ & $11.6 \mathrm{a}$ & $11.4 \mathrm{a}$ & $11.3 \mathrm{a}$ & $11.4 \mathrm{a}$ \\
\hline$\%$ & & & & & & \\
\hline $\begin{array}{l}\text { IVDMD } \\
\%\end{array}$ & $44.8 \mathrm{~d}$ & $57.6 \mathrm{a}$ & $55.0 \mathrm{~b}$ & $54.1 \mathrm{~b}$ & $50.4 \mathrm{c}$ & $49.8 \mathrm{c}$ \\
\hline $\begin{array}{l}\mathrm{CC} \\
\%\end{array}$ & $58.8 \mathrm{e}$ & $73.4 \mathrm{a}$ & $72.3 \mathrm{ab}$ & $70.9 \mathrm{bc}$ & $69.3 \mathrm{~cd}$ & $67.8 \mathrm{~d}$ \\
\hline
\end{tabular}

'Means in the same row sharing the same superscript are not significantly different at the 0.05 level.

It seems also that sunlight plays a significant role in the chemical composition and nutritive value of kermes oak browse. Using Kjeldahl analysis (AOAC 1975) for nitrogen determination, total nonstructural carbohydrate determination analysis (Smith et al. 1964, AOAC 1975), and spectrometric method for tannin determination (Burns 1963), Koukoura (1984) found that crude protein content of kermes oak growing as an understory of a Pinus brutia Ten. forest $(80 \%$ cover) was higher $(10.1 \%)$ than that of unshaded shrubs $(8.5 \%)$. She also found that lignin was $15.8 \%$ and $11.5 \%$ respectively, while foliage soluble carbohydrates were much higher in unshaded than in shaded areas $\left(129.8 \mathrm{mg} \cdot \mathrm{g}^{-1}\right.$ and 114.5 $\mathrm{mg} \cdot \mathrm{g}^{-1}$ respectively).

\section{Improvements for Increasing Productivity}

The high productive potential of kermes oak shrublands requires proper management to ensure the optimal benefit to grazing animals. The need for research related to this objective was realized by the time this high potential was recognized.

In 1982, a kermes oak shrubland was fertilized with ammonium phosphate ( $50 \mathrm{~kg} \mathrm{~N}$ and $60 \mathrm{~kg} \mathrm{P}_{2} \mathrm{O}_{5}$ per ha) every second year. Yearling goats grazed on the shrubland all year round. The early results ( 3 years) showed that fertilization resulted in a significant increase of animal gains as compared to the control $\left(60 \mathrm{~kg}^{-\mathrm{ha}^{-1}}\right.$ and $34 \mathrm{~kg} \bullet \mathrm{ha}^{-1}$ live weight respectively) (Papanastasis personal communication). However, this increase was probably due to the response of the herbaceous plants rather than that of the kermes oak. Poissonet et al. (1981) reported that crushing and fertilizing a garrigue vegetation in Southern France with $100 \mathrm{~kg}^{\circ} \mathrm{ha}^{-1} \cdot \mathrm{yr}^{-1}$ of $\mathrm{N}$, of $\mathrm{P}_{2} \mathrm{O}_{5}$ and of $\mathrm{K}_{2} \mathrm{O}$ resulted in a 10 -fold increase of stocking rate $\left(5\right.$ sheep $\bullet$ year $\left.{ }^{-1} \bullet \mathrm{ha}^{-1}\right)$ compared to the control $(0.5$ sheep $\bullet$ year ${ }^{-1} \cdot$ ha $\left.^{-1}\right)$.

The productivity of kermes oak shrubland converted to grassland was compared to improved kermes oak shrubland under animal grazing conditions (Liacos et al. 1980). Prescribed fire was used to burn a tall ( $2 \mathrm{~m}$ in height) and very dense kermes oak shrubland (95\% Quercus coccifera and $5 \%$ other shrubs) in order to eliminate the above-ground part of the shrubs. The burned site was

Table 5. Crude protein content of kermes oak browse under various clipping intensities, and at different phenological stages (After Tsiouvaras 1984).

\begin{tabular}{|c|c|c|c|c|c|c|}
\hline \multirow[b]{2}{*}{$\begin{array}{l}\text { Phenological } \\
\text { stages }\end{array}$} & \multicolumn{6}{|c|}{ Clipping intensities } \\
\hline & $\begin{array}{c}0 \% \\
\text { Control }\end{array}$ & $20 \%$ & $40 \%$ & $60 \%$ & $80 \%$ & $100 \%$ \\
\hline $\begin{array}{l}\text { Rapid growth } \\
\text { (Spring) }\end{array}$ & $16.1 \mathrm{~b}^{1}$ & $17.1 \mathrm{ab}$ & $17.4 \mathrm{a}$ & $17.0 \mathrm{ab}$ & $16.5 \mathrm{ab}$ & $16.7 \mathrm{ab}$ \\
\hline $\begin{array}{l}\text { Stem hardening } \\
\text { (Summer) }\end{array}$ & $7.3 \mathrm{~g}$ & $10.0 \mathrm{def}$ & $10.0 \mathrm{def}$ & $-9.7 \mathrm{f}$ & $9.7 \mathrm{f}$ & 9.8 ef \\
\hline $\begin{array}{l}\text { Secondary growth } \\
\text { (Early fall) }\end{array}$ & $8.0 \mathrm{~g}$ & $11.3 \mathrm{c}$ & $11.0 \mathrm{~cd}$ & $10.8 \mathrm{cde}$ & 10.6 cdef & $10.8 \mathrm{cde}$ \\
\hline
\end{tabular}

'Means sharing the same superscript are not significantly different at the 0.05 level. 
seeded with Dactylis glomerata L. Bromus inermis Leysser, Phalaris aquatica L., Lolium multiflorum Lam. and Lotus corniculatus L. (Fig. 1). At the same time in an adjacent shrubland, composed of

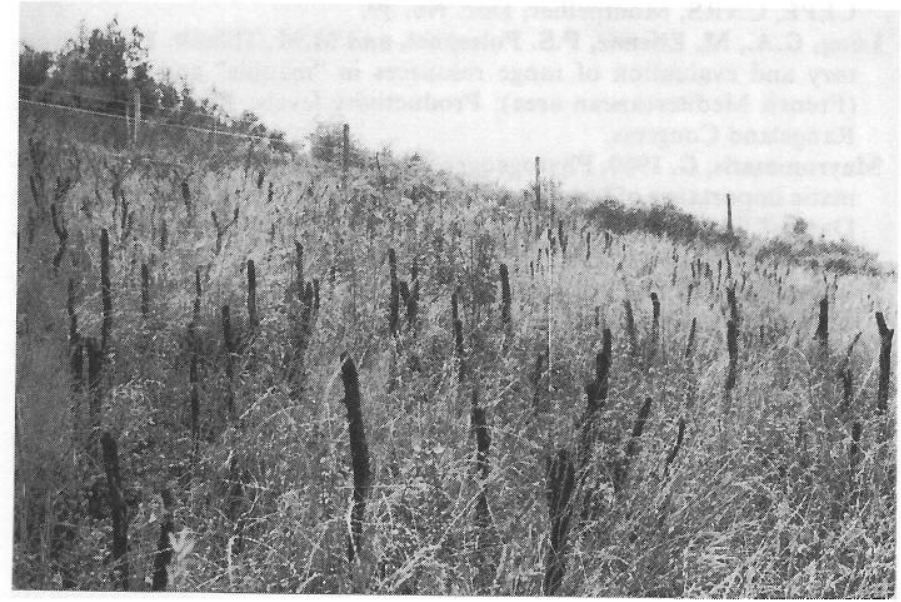

Fig. 1. The kermes oak shrubland converted to grassland the first year after the conversion. In the background is the unimproved kermes oak shrubland.

the 5 types of kermes oak, all the individuals of the less palatable and less productive types of kermes oak were removed manually resulting in a crown density of 0.8 . The remaining plants were topped to a height of $0.8 \mathrm{~m}$, to make them accessible to grazing animals (Fig. 2).

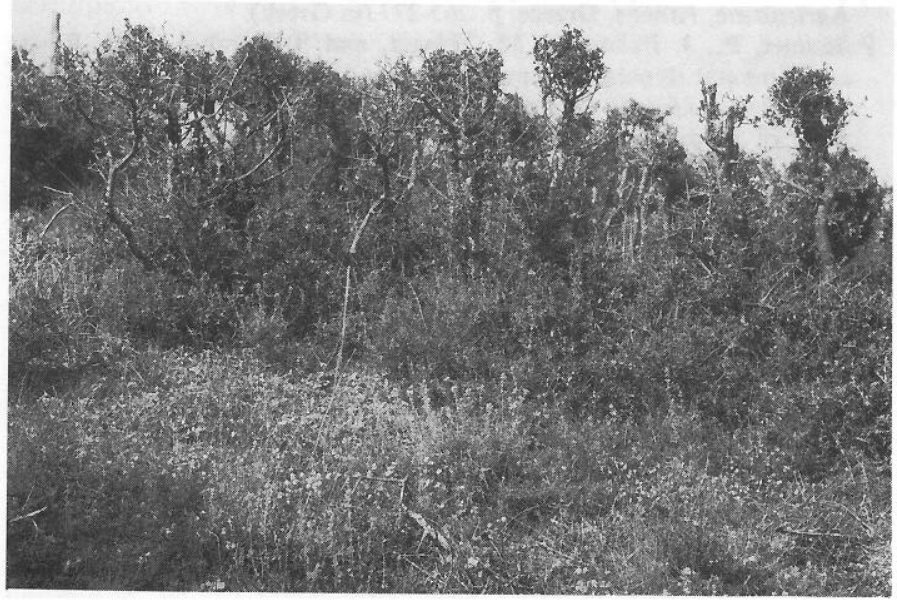

Fig. 2. The improved kermes oak shrubland the third year after top cutting to a height of $0.8 \mathrm{~m}$, and grazing.

After a protection period of 1 growing season, the converted shrubland was grazed for 2 months in the spring, while the improved shrubland was grazed for 10 months (October-July) each year, for 3 consecutive years. The animals used were 6 to 12-month-old goats. The liveweight gains in the converted shrubland and the improved shrubland are shown in Table 6. After the first year of high acorn production, the mean meat production in the improved shrubland stabilized at about $56 \mathrm{~kg} \bullet \mathrm{ha}^{-1} \bullet \mathrm{yr}^{-1}$, while in the converted, it was about 1.5 times greater but showed a declining trend attributed to the overgrazing of the seeded grass species and the increase of kermes oak sprouts and unpalatable species (Cistus spp.). Both treatments exceeded the meat production $\left(25 \mathrm{~kg} \bullet \mathrm{ha}^{-1}\right)$ obtained when a tall and dense (unimproved) stand of kermes oak was grazed by adult goats from October to June for 4 consecutive years (Liacos and Moulopoulos 1967).

\section{Management Implications}

These research findings suggest some management techniques
Table 6. Goat liveweight meat production $\left(\mathrm{kg} \bullet \mathrm{ha}^{-1}\right)$ from kermes oak shrublands under different states of improvement in Northern Greece (After Liacos et al. 1980).

\begin{tabular}{lcc}
\hline \hline Treatment Years & $\begin{array}{c}\text { Converted shrubland } \\
\text { to grassland }\end{array}$ & $\begin{array}{c}\text { Improved } \\
\text { shrubland }\end{array}$ \\
\hline 1976 & 119.4 & 72.8 \\
1977 & 97.7 & 56.8 \\
1978 & 79.5 & 55.8 \\
\hline
\end{tabular}

for kermes oak shrubland aimed at procurring the optimum yield of forage and livestock products. The results to date show that improving kermes oak shrublands, either by converting them to grasslands, by mechanical means, by using prescribed fire, or by manual cutting (top or base cutting) and removing the unpalatable types, is effective in increasing the liveweight gains by a factor of 2-4 and the browse production by a factor of 4 . However, the economic returns from such practices have not yet been determined.

A combination of low and more open forms of kermes oak shrublands might be more productive than tall and dense ones. This form is now being investigated for 3 different densities of kermes oak in combination with herbaceous vegetation. The alternatives are as follows: $70 \%$ grass $30 \%$ brush, $50 \%$ grass $50 \%$ brush, and $30 \%$ grass $70 \%$ brush cover. The purpose is to achieve optimum production and a better quality of forage in order to meet animal demands for longer periods of the year. Under these conditions, animal production will be increased while the need for supplementation will be reduced. A considerable contribution to nutritious forage for grazing animals is made by kermes oak, growing under the canopy of pine forests. Its productivity, nutritive value, and phenology can be of great importance in an integrated grazing system with adjacent grasslands and/or shrublands.

Kermes oak shrublands comprise a fire adapted ecosystem. These communities depend on fire for their existence and maintenance. Kermes oak is a fire resistant species and sprouts vigorously after burning (Le Houerou 1974, Naveh 1974, Trabaud 1977, Papanastasis 1978). In southern France (Trabaud 1977), kermes oak stands start degenerating at an age of between 20 and 30 years, given no fire. So the periodic use of prescribed fire in kermes oak is ecologically justified, and it could effectively create a mosaic of tall and shorter shrubs. The use of a combination of grazing and fire could maintain a balance between the herbaceous plants and the kermes oak by controlling the sprouts and enhancing productivity. The food preferences of goats include a considerable amount of browse, thus they can utilize and effectively control kermes oak sprouts.

Tsiouvaras (1984), testing various twig clipping intensities on a low and open form of kermes oak shrubland, suggested a rotation grazing system. The shrubland must be divided into 2 parts and, starting in late April (for northern Greece), the pastures should be grazed by goats alternately for 15 days until the end of August. Utilization must not exceed $60 \%$ of twig length for a period of 2 years, in order to permit heavier grazing in the event of unexpected drought and in order to sustain winter grazing. The implementation of this rotation system offers new (re-growth), more palatable, and more nutritious browse to grazing animals throughout the growing period.

The conversion method, either by fire or by mechanical means, generally requires deep soil and gentle slopes. Hence, it can only be applied to the most productive sites of the kermes oak shrublands. Liacos et al. (1980) suggest that conversion of kermes oak shrublands to grasslands in Greece should not be applied to sites with a soil depth of less than $30 \mathrm{~cm}$ and a slope of more than $25 \%$, because such sites are less productive and there is a high risk of soil erosion.

One more factor that must be considered in selecting the conversion method is the loss of nutrients from the system, which can 
result in decreased site fertility. Fire temporarily increases site fertility but in the long run soil nutrients decline (Vlamis and Gowans 1961, De Bano 1974, Papanastasis 1976). Manual or mechanical clearing and removal of debris may lead to the loss of the system's nutrients, while mechanical chopping with the debris left in place appears to maintain site fertility better (Hollinger 1982). However, it sems that a combination of conversion and sprout control methods would be the best and the most economically justified (Biswell 1954, Bentley 1967, Murphy et al. 1975).

\section{Conclusions}

Management of kermes oak shrublands should focus on the creation of a combination of the most productive forms of vegetation. This can be achieved by converting the shrublands to grasslands in the most productive sites and retaining the low form of the shrubs mixed with grasses in the less productive sites. The shrublands growing as a pine forest understory should receive the same treatment (low form). Such a mosaic of vegetation will best exploit the site potential and better meet the year-long food requirements of grazing animals. It will secure the soil stability, protect the watersheds and serve hydrological purposes, and generally improve the aesthetic value of the landscape. All these aspects should be considered in the management of kermes oak shrublands in the Mediterranean countries.

\section{Literature Cited}

A.O.A.C. 1975. Official methods of analysis (12th Ed.). Association of Official Analytical Chemists. Washington D.C.

Bentley, J.R. 1967. Conversion of chaparral areas to grassland. USDA Agr. Hand. 328.

Biswell, H.N. 1954. The brush control problem in California. J. Range Manage. 7:57-62.

Burns, R.E. 1963. Methods of tannin analysis for forage crop evaluation. Univ. of Georgia Agr. Exp. Sta. Tech. Bull. N.S. 32.

Cook, C.W. 1972. Comparative nutritive values of forbs, grasses and shrubs. In:C.M. McKell, J.P. Blaisdell and J.R. Goodin, eds.: Wild land Shrubs-Their Biology and Utilization. Ogden, Utah, USDA, Forest Serv. Gen. Tech. Rep. INT-1.

Dafis, S. 1973. Forest classification in Greece. Annals of Agriculture and Forestry School, Vol. IE', p. 73-90, University of Thessaloniki, Greece. (In Greek, summary in German).

De Bano, L.F. 1974. Chaparral soils. p. 19-26. In: Proc. Symp. on Living with the Chaparral. 1973 March 30-31, Riverside, Calif. San Francisco, Calif. Sierra Club.

Emberger, L. 1942. Un projet d'une classification des climats du point de vue phytogeographique. Bul. Soc. D'Histoire Naturelle de Toulouse. 77:97-124.

Fahn, A. 1974. Plant anatomy. Pergamon Press. p. 611.

Hollinger, D.Y. 1982. The effect of fuel management on nutrients in a chaparral ecosystem. In: Proc. Symp. on Dynamics and Management of Mediterranean-type ecosystems. San Diego, Calif. PSW Forest and Range Exp. Sta. Gen. Tech. Rep. PSW-58.

Koukourn, Z. 1984, Production and forage quality of kermes oak (Quercus coccifera L.) under various light intensities. Diss. Dep. Forestry. Univ. of Thessaloniki, Greece. (In Greek, summary in English).

Kramer, P.J., and T.T. Kozlowski. 1960. Physiology of trees. McGraw-Hill Book Co., N.Y.

Le Houerou, H.N. 1972. Africa, the Mediterranean region. In: C.M. McKell, J.P. Blaisdell, and J.R. Goodin (eds.): Wildland Shrubs-Their Biology and Utilization. USDA Forest Serv. Gen. Tech. Rep. INT-1.

Le Houerou, H.N. 1974. Fire and vegetation in the Mediterranean basin. Proc. 13th Annual Tall Timbers Fire Ecology Conf.

Le Houerou, H.N. 1980. Chemical composition and nutritive value of browse in tropical West Africa-The Current State of Knowledge. In: Internat. Symp. Browse in Africa. Intern. Livestock Centre for Africa. Addis Ababa, Ethiopia.

Llacos, L.G., and C. Moulopoulos. 1967. Contribution to the identification of some range types of Quercus coccifera L. North Greece Forest Res. Center, Res. Bull. No. 16. (In Greek, summary in English).

Liacos, L.G., V.P. Papanastasis, and C.N. Tsiouvaras. 1980. Contribution to the conversion of kermes oak (Quercus coccifera L.) brushlands to grasslands and comparison of their productivity with improved brush- ands in Greece. "Dassiki Erevna" Vol. 2/1/1980. p. 97-142. Athens Forest Res. Inst. (In Greek, summary in English).

Long, G., F. Fay, M. Thiault, and L. Trabaud. 1967. Essai de determination experimentale de la productivite d'une garrique a Quercus coccifera. CEPE, CNRS, Montpellier, Doc. No. 39.

Long, G.A., M. Etienne, P.S. Poissonet, and M.M. Thiault. 1978. Inventory and evaluation of range resources in "maquis" and "garriques" (French Mediterranean area): Productivity levels. Proc. 1st Internat. Rangeland Congress.

Mavrommatis, G. 1980. Phytogeographical, phytosociological and bioclimatic importance of kermes oak (Quercus coccifera L.) brushlands. "To Dassos" 90:72-76. Ministry of Agriculture, Athens, Greece. (In Greek, summary in French).

Moulopoulos, C. 1965. Silviculture. Agr. and For. School, University of Thessaloniki, Greece. (In Greek).

Murphy, A.H., O.A. Leonard, and D.T. Torell. 1975. Chaparral shrub control as influenced by grazing, herbicides and fire. Down to Earth. 31:3.

Nastis, A.S. 1982. Nutritive value of oak browse (Quercus coccifera L.) foliage for goats at various phenological stages. Dissertation. Dep. of For. Univ. of Thessaloniki, Greece. (In Greek, summary n English).

Naveh, Z. 1974. The ecology of fire in Israel. Proc. 13th Annual Tall Timbers Fire Ecology Conf.

Papanastasis, V.P. 1976. Factors involved in the decline of annual ryegrass seeded on burned brushlands in California. J. Range Manage. 29:244247.

Papanastasis, V.P. 1978. Early succession after fire in a maquis type brushland in Northern Greece. "To Dassos”, 30:19-26. Ministry of Agriculture, Athens, Greece. (In Greek, summary in English).

Papanastasis, V.P., and L.G. Liacos. 1980. Productivity and management of kermes oak brushlands for goats. In: Internat. Symp. Browse in Africa - The Current State of Knowledge (Ed. N.H. Le Houerou). Intern. Livestock Centre for Africa, Addis Ababa, Ethiopia.

Pittas, A.C. 1980. Natural rangelands. "Dassika Chronika". Ministry of Agriculture, Athens, Greece. p. 263-277 (in Greek).

Poissonet, P., J. Poissonet, M. Thiault, and S. Rambul. 1981. Range experimental dynamics, management and hydrology in "garrigue" of Quercus coccifera L. (S. France). Proc. Symp. Dynamics and Management of Mediterranean-Type Ecosystems. USDA, Forest Serv. Gen. Tech. Rep. PSW-58.

Short, H.L., R.M. Blair, and L. Burkart. 1972. Factors affecting nutritive values. In: C.M. McKell, J.P. Blaisdell, and J.R. Goodin, eds: Wildland Shrubs-Their Biology and Utilization. Ogden, Utah USDA, Forest Serv. Gen. Tech. Rep. INT-1.

Smith, D.G., M. Paulsen, and C.A. Raguse. 1964. Extraction of total soluble carbohydrates from grass and legume tissue. Plant Physiol. 39:960-962.

Street, J.C., J.E. Butcher, and L.E. Harris. 1964. Estimating urine energy from urine nitrogen. J. Anim. Sci. 23:1039-1041.

Tilley, J.M.A., and R.A. Terry. 1963. A two-stage technique for the in vitro digestion for forage crops. J. Brit. Grass. Soc. 18:104-111.

Trabaud, L. 1977. Comparison between the effect of prescribed fires and wild fires on the global quantitative evolution of the kermes scrub oak (Quercus coccifera) garriques. Proc. Symp. Envir. Conseq. of Fire and Fuel Manage. in Mediterranean Ecosystems. USDA Forest Serv. Gen. Tech. Rep. WO-3.

Tslouvaras, C.N. 1978. Twig diameter-length-weight relations of Quercus coccifera L. Ann. Agr. and Forestry School. Vol. 21:137-152. Univ. of Thessaloniki, Greece. (In Greek, summary in English).

Tslouvaras, C.N. 1984. Effects of various clipping intensities on browse production and nutritive value of kermes oak (Quercus coccifera L.). Diss. Dep. of Forestry, Univ. of Thessaloniki, Greece. (In Greek, summary in English)

Tsiouvaras, C.N., B. Noitsakis, and V.P. Papanastasis. 1986. Clipping intensity improves growth rate of kermes oak twigs. Forest Ecol. and Manage. 15:229-237

Tutin, T.G., V.H. Heywood, N.A. Burges, D.M. Moore, D.H. Valentine, S.M. Walters, and D.A. Webb. 1964-1980. Flora Europaea. Vol. I-V. Cambridge Univ. Press. London, New York.

Van Soest, P.J. 1963. Use of detergents in the analysis of fibrous feeds. II. A rapid method of the determination of fiber and lignin. J. Ass. Off. Agr. Chem. 48:829-835.

Van Soest, P.J. 1967. Development of a comprehensive system of feed analyses and its application to forages. J. Anim. Sci. 26:119-128.

Vlamis, J., and K.D. Gowans. 1961. Availability of nitrogen, phosphorus and sulphur after brush burning. J. Range Manage. 14:38-40.

Vlamis, J., and K.D. Gowans. 1961. Availability of nitrogen, phosphorus and sulphur after brush burning. J. Range Manage. 14:38-40.

JOURNAL OF RANGE MANAGEMENT 4O(6), November 1987 